いびき音信号を用いた呼吸ルートの自動識別に関する基礎的検討

$$
\text { 非会員 三上 剛* 正 員 小島洋一郎* }
$$

\author{
Automatic Recognition of Breathing Route During Sleep Using Snoring Sounds
}

Tsuyoshi Mikami*, Non-member, Yohichiro Kojima*, Member

（2010年 11 月 29 日受付， 2011 年 4 月 29 日再受付）

\begin{abstract}
This letter classifies snoring sounds into three breathing routes (oral, nasal, and oronasal) with discriminant analysis of the power spectra and $k$-nearest neighbor method. It is necessary to recognize breathing route during snoring, because oral snoring is a typical symptom of sleep apnea but we cannot know our own breathing and snoring condition during sleep. As a result, about $98.8 \%$ classification rate is obtained by using leave-one-out test for performance evaluation.
\end{abstract}

キーワード : いびき音, 呼吸ルート, 判別分析, $k$-最近傍法

Keywords: Snoring Sounds, Breathing Route, Discriminant Analysis, $k$-Nearest Neighbor Method

1. はじめに

睡眠時の呼吸は主に鼻呼吸によって行われているが，鼻 づまりなどが原因で鼻腔の通気性が不良となり口呼吸状態 に至ると, 上気道の狭窄が起こり易く, いびきを増強させ て閉塞型睡眠時無呼吸 (Obstructive Sleep Apnea; OSA) の発生につながることが指摘されている(1)。OSAにおいて 口呼吸によるいびきは必発の症状であり ${ }^{(2)}$, その早期発見 と適切な治療を行うことが重要となる。しかし, 睡眠時の 呼吸やいびきの状態を本人が自覚する事はほとんど不可能 であり，専門の医療機関での検査が必要になる ${ }^{(2)}$ が, 入院 を要したり，多数のセンサを体に装着することから，肉体 的，精神的負担が大きい。したがって，自宅でより簡便に 口呼吸いびきの発生を検出する呼吸モニタリング装置の開 発が望まれる。本論では，無浸襲かつ容易に取得できるい びき音に着目し，いびき音の信号のみから呼吸ルート（口 呼吸, 鼻呼吸, 口鼻呼吸) を識別する手法を提案する。

2. いびき音の取得

被験者は健康な男女 6 名（60 歳台の男女それぞれ 1 名, 30 歳台の男性 3 名, 20 歳台の男性 1 名）であり, 起きてい る状態で模擬的に発生したいびきを録音した。この模擬いび き ${ }^{(3)}$ は，生理学研究でしばしば用いられる手法である。被 験者は仰臥し，鼻呼吸いびきを録音する際には口を完全に 閉じて模擬いびきを発生し，口呼吸いびきを録音する際に は指で鼻を完全に塞いだ状態で発生した。また, 口鼻呼吸い

\footnotetext{
* 国立苫小牧工業高等専門学校

厂 059-1275 北海道苫小牧市字錦岡 443 番地

Tomakomai College of Technology

443, Nishikioka, Tomakomai, Hokkaido 059-1275, Japan
}

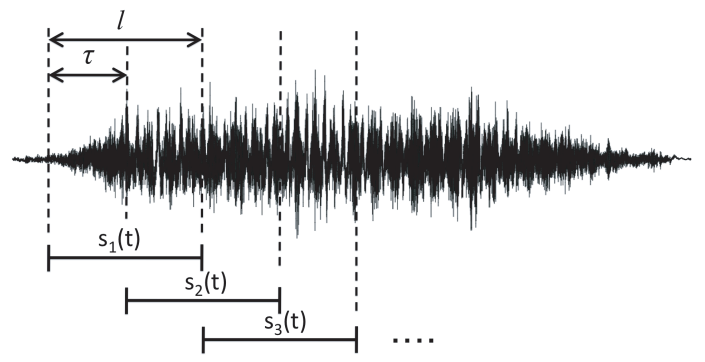

Fig. 1. The $i$ th subsequence whose length is $l$ is extracted from an episode with $\tau$ steps

びきを録音する際には, 被験者は口をやや開き, かつ鼻を塞 がない自然な状態で模擬いびきを発生した。測定器はリニア PCM レコーダ（Olympus LS-10）を用い，被験者の鼻の 先端から約 $10 \mathrm{~cm}$ の位置に固定した。マイクの指向性はオ フに設定し, サンプリング周波数 $\left(F_{s}\right)$ を $44.1 \mathrm{kHz}$ ，量子 化ビット数を 16 bit に設定した。 1 人の被験者につき， 3 つ の異なる呼吸ルートの模擬いびきをそれぞれ 16〜20秒間発 生したものを録音した。録音データから 1 回の吸気に伴って 発生したいびき音（エピソード）を手作業で切り出した。

\section{3. 呼吸ルートの自動識別方法}

〈3・1〉 部分時系列の作成 いびき音は振幅と周波数特 性が時間経過と共に変化する非定常な信号 (4)であり, Dalmasso らはエピソードに対し音声認識で一般的な短時間フー リ工変換を用いて周波数特性を求めている。本論で取得し た模擬いびき音のエピソードにも非定常性が見受けられた ため, エピソード全体ではなく, その一部を切り出した部 分時系列に対して検討することにした。 

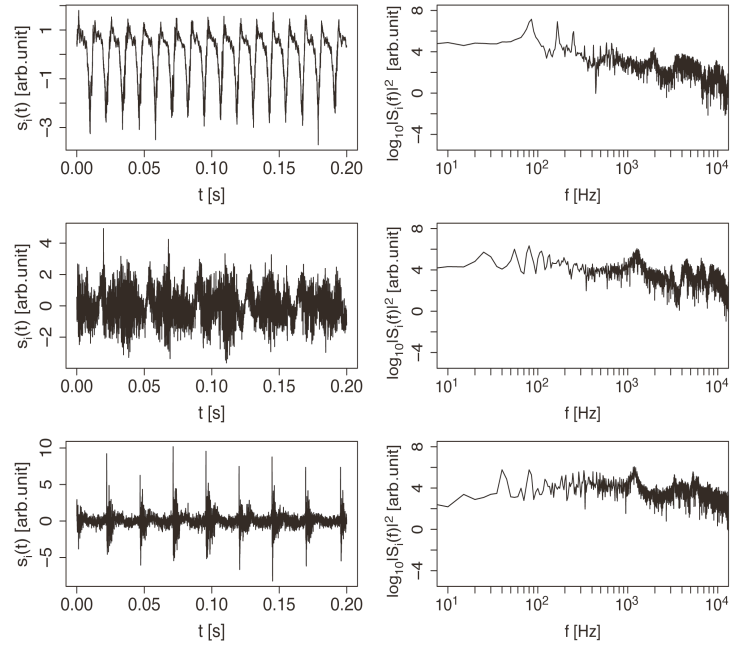

Fig. 2. Waveforms and power spectra of the subsequences extracted from oral (top), nasal (middle), and oronasal (bottom) snoring sounds

各エピソードから,$l=0.2$ 秒の長さの部分時系列を $\tau=0.1$ 秒毎に切り出し, $i$ 番目に切り取った部分時系列を $s_{i}(t)$ と書くことにする（図 1)。すべてのエピソードから 部分時系列を切り出した結果, 鼻呼吸から 235 個, 口呼吸 から 251 個，口鼻呼吸から 181 個，合計 667 個の部分時系 列を取得した。また，音量に個人差があったので，部分時 系列の振幅は平均 0 分散 1 となるように正規化した。

$\langle 3 \cdot 2\rangle$ 特徵抽出 部分時系列 $s_{i}(t)$ に対して FFT を 用いてパワースペクトル $\left|S_{i}(f)\right|^{2}$ を計算した（図 2$)$ 。その 結果，呼吸ルートによる音響特性の違いは明瞭で，3つの 波形は $20 \mathrm{~Hz} \sim 80 \mathrm{~Hz}$ 程度の基本周波数を有し，主に低周 波領域にその特徵が現れていることがわかる。また， $1 \mathrm{kHz}$ 付近にもピークが見られ， $3 \mathrm{kHz}$ 以上の高周波にも特有の 形状が見受けられることから，本論では一部の帯域のみに 限定せず， $0 \mathrm{~Hz}$ から理論上の最大周波数である $F s / 2 \mathrm{~Hz}$ ま でのパワースペクトル全体の值を用いることにした。

パワースペクトルは, 部分時系列の長さ $l$ が 0.2 秒であ るため, $F_{s} / 2 \times l=4,410$ 点で表される離散的なスペクト ルとなる。これを 4,410 次元のベクトルとし，スペクトル デー夕と呼ぶことにする。その後，スペクトルデー夕に対 して判別分析を行い，異なる呼吸ルートに属するデー夕は 互いに離れた位置に，同一呼吸ルートに属するデー夕は互 いに近い位置に分布するような部分空間（判別空間）を求 め, 特徵ベクトルとする。ところが本論で用いるスペクト ルデー夕は，デー夕数より次元数が大きいのでクラス内共 分散行列が特異となり，このままでは判別分析を適用でき ない。これは画像認識など高次元のデー夕を扱う際に共通 する問題であり，Belhumeur ら (5) は主成分分析を用いて， デー夕数以下の次元の部分空間にあらかじめ射影した後，判 別分析を適用する手法を提案している。本論も Belhumeur らの手法を用いることにした。

まず，スペクトルデー夕に対して主成分分析を行い，い
Table 1. Recognition rate by 3-nearest neighbor method using the first 310 principal components.

\begin{tabular}{l|lrrr}
\hline Breath & Recog. Rate(\%) & \multicolumn{3}{|c}{ Recognition Result } \\
& & Nasal & Oral & Oronasal \\
\hline Nasal & $234 / 235(99.6 \%)$ & 234 & 0 & 1 \\
Oral & $247 / 251(98.4 \%)$ & 0 & 247 & 4 \\
Oronasal & $178 / 181(98.3 \%)$ & 1 & 2 & 178 \\
\hline total & $659 / 667(98.8 \%)$ & & & \\
\hline
\end{tabular}

びき音の特徵を保持したまま, より低次元 $(m$ 次元 $)$ の主 成分空間を構成し，すべてのスペクトルデー夕を主成分空 間に射影した。その後，主成分空間内における $m$ 次元の特 徵べクトルに対し，クラス内分散とクラス間分散の比を最 大にする基準から判別空間を構成した。判別空間の次元数 は理論的にクラス数 -1 となり ${ }^{(6)}$, 本論ではクラス数は呼 吸ルート数の 3 に対応するため, $m$ 次元の主成分空間内の 特徵ベクトルは最終的に 2 次元の判別空間に射影される。

$\langle\mathbf{3} \cdot \mathbf{3}\rangle$ 識別処理 判別空間内に射影された特徵ベク トルに対して識別処理を行なう。識別処理の手法は多数提 案されているが, ここでは $k$-最近傍法 ${ }^{(6)}$ を用いることにし た。この手法のパラメータである $k$ の值は 3 に設定し, 識 別率は 1 つ抜き法 (Leave-one-out method) (6)で求めた。

\section{4. 実験結果}

主成分空間の次元 $m$ を 10 から 660 まで設定し，各々の 次元数に設定した時の識別率を求めたところ，310 までは 識別率が増加したが，それ以降は逆に識別率が低下した。

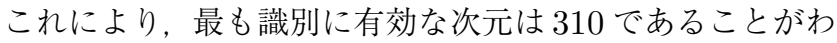
かった。次に，次元数を 310 に設定したときの識別結果の 詳細を表 1 に示す。鼻呼吸を口鼻呼吸と誤ったケースが 1 例，口呼吸を口鼻呼吸と誤ったケースが 4 例あった。しか し，口呼吸を鼻呼吸と誤ったケースはなく，その逆もなかっ た。したがって，口鼻呼吸は，口呼吸と鼻呼吸のちょうど中 間の特性を有しているが，やや口呼吸に類似しており，一 方で，口呼吸と鼻呼吸との違いは顕著と考えられる。

5. まとめ

本論では，いびき音のパワースペクトルに対して，主成 分分析と判別分析を適用し特徵ベクトルを求めた。 $k$-最近 傍法で識別処理をすることで，3つの呼吸ルートを最大で $98.8 \%$ 識別することが出来た。

\section{文献}

(1) 市岡正彦:「呼吸器と睡眠異常」, 日本薬理学雑誌, Vol.129, No.6, pp.432-435 (2007)

（2）本間 栄: 「睡眠時無呼吸症候群」, 改訂第 2 版, 克誠堂出版 (2009)

(3) G. Liistro, D. Stanescu, and C. Veriter: "Pattern of simulated snoring is different through mouth and nose", J. Appl. Physiol., Vol.7, No.6, pp.2736-2741 (1991)

(4) F. Dalmasso and E. Prota: "Snoring: analysis, measurement, clinical implications and applications", Eur. Respir. J., Vol.9, pp.146-159 (1996)

(5) P. N. Belhumeur, J. P. Hespanha, and D. J. Kriegman: "Eigenfaces vs Fisherfaces: Recognition using Class Specific Linear Projection", IEEE Trans. Pattern Anal. Mach. Intell., Vol.19, No.7, pp.711-720 (1997)

（6）石井健一郎・前田英作・上田修功・村瀬 洋 :「わかりやすいパ夕ー ン認識」, オーム社 (1998) 